\title{
PENGARUH MODEL PEMBELAJARAN INKUIRI TERBIMBING DAN MINAT BELAJAR TERHADAP KETERAMPILAN PROSES SAINS PADA SISWA KELAS IV SD
}

\author{
Ni Kadek Metaputri, Ni Nym. Garminah \\ Jurusan Pendidikan Guru Sekolah Dasar, Fakultas Ilmu Pendidikan \\ Universitas Pendidikan Ganesha, Jln. Udayana No. 11 Singaraja \\ e-mail: metaprince@gmail.com
}

\begin{abstract}
This research was aimed to know the effect of guided inquiry learning toward science process skills with controlling interest in learning. The research using non-equivalent post-test only control group design. The population in this research was all of the fourth grade student in SD Negeri 1 Astina in academic years 2015/2016. The sample was taken out using simple random sampling. The collected data were analyzed by one way Ancova with one covariable. The research showed that: (1) there are significant differences in science process skills between the group of students who studied with guided inquiry learning and the group of student who didn't study with guided inquiry learning ( $\mathrm{F}$ $=4,346$, with Sig. $=0,042<0,05) ;(2)$ there are significant differences in science process skills between the group of students who studied with guided inquiry learning and the group of student who didn't study with guided inquiry learning after controlling the interest in learning $(F=4,150$, with Sig. $=$ $0,047<0,05)$; and (3) there are significant correlation of the interest in learning with science process skills (Sig. $=0,000<0,05$ ). Thus, there are the significant influence of Guided Inquiry model of learning toward science process skills after controlling learning interest.
\end{abstract}

Keywords: guided inquiry learning, science process skills, the interest in learning

\begin{abstract}
ABSTRAK: Penelitian ini bertujuan untuk mengetahui pengaruh model pembelajaran Inkuiri Terbimbing terhadap keterampilan prosess sains dengan mengontrol minat belajar. Rancangan penelitian yang digunakan adalah non-equivalent post-test only control group design. Populasi dalam penelitian ini adalah siswa kelas IV SD Negeri 1 Astina tahun pelajaran 2015/2016. Sampel diambil dengan teknik simple random sampling. Data yang telah dikumpulkan dianalisis dengan uji Anakova 1 jalur 1 kovariabel. Hasil penelitian menunjukkan bahwa (1) terdapat perbedaan yang signifikan keterampilan proses sains antara kelompok siswa yang dibelajarkan dengan model pembelajaran Inkuiri Terbimbing dan kelompok siswa yang dibelajarkan dengan pembelajaran konvensional $(\mathrm{F}=4,346$, dengan Sig. $=0,042<0,05)$; (2) terdapat perbedaan yang signifikan keterampilan proses sains antara kelompok siswa yang dibelajarkan dengan model pembelajaran Inkuiri Terbimbing dan kelompok siswa yang dibelajarkan dengan pembelajaran konvensional setelah mengontrol minat belajar $(\mathrm{F}=$ 4,150 , dengan Sig. $=0,047<0,05$ ); (3) terdapat korelasi yang signifikan antara minat belajar dengan keterampilan proses sains $($ Sig. $=0,000<0,05)$. Dengan demikian, terdapat pengaruh model pembelajaran Inkuiri Terbimbing terhadap keterampilan proses sains dengan mengontrol minat belajar.
\end{abstract}

Kata-kata kunci: pembelajaran Inkuiri terbimbing, keterampilan proses sains, minat belajar

Pendidikan merupakan salah satu kebutuhan hidup manusia dalam usahanya untuk mempertahankan hidup dan mengembangkan diri masyarakat. Maju dan berkembangnya suatu negara tergantung dari kualitas pendidikan yang dimiliki. Melalui pendidikan manusia akan terbebas dari keterbelakangan, kebodohan, dan bahkan terbebas dari kemiskinan. Pendidikan yang berkualitas akan menghasilkan sumber daya manusia yang berkualitas pula, sehingga mampu 
mengembangkan kemampuan berpikir agar sadar ilmu pengetahuan teknologi dan seni (IPTEKS), serta mampu mengikuti dan memanfaatkan perkembangan tersebut. Pendidikan merupakan hal mutlak yang harus dipenuhi secara optimal di era globalisasi seperti saat ini, pendidikan akan dapat meningkatkan daya saing dan kualitas sumber daya manusia (SDM). Pengaruh SDM sejalan dengan tujuan pendidikan nasional yaitu mencerdaskan kehidupan bangsa untuk meningkatkan sumber daya manusia yang berkualitas. Tujuan pendidikan nasional ditegaskan dalam UU No. 20 Tahun 2003, Bab II pasal 3, yaitu sebagai berikut.

Pendidikan nasional berfungsi mengembangkan kemampuan dan membentuk watak serta peradaban bangsa yang bermartabat dalam rangka mencerdaskan kehidupan bangsa, bertujuan untuk berkembangnya potensi peserta didik agar menjadi manusia yang beriman dan bertakwa kepada Tuhan Yang Maha Esa, berakhlak mulia, sehat, berilmu, cakap, kreatif, mandiridan menjadi warga negara yang demokratis serta bertanggung jawab.

Kutipan tersebut membuktikan bahwa pendidikan nasional bertujuan untuk memberikan arah pada semua kegiatan pendidikan dalam satuan-satuan pendidikan yang ada. Tujuan pendidikan nasional tersebut merupakan tujuan umum yang hendak dicapai oleh semua satuan pendidikan. Meskipun setiap satuan pendidikan tersebut mempunyai tujuan sendiri, namun azasnya terlepas dari tujuan pendidikan nasional.

Tujuan pendidikan nasional yang bertujuan untuk mencerdaskan kehidupan bangsa dapat dikatakan belum tercapai, bisa dilihat dari banyaknya siswa masih pasif dalam mengikuti pembelajaran. Selain itu, dapat juga kita lihat di layar televisi bagaimana pendidikan di Indonesia yang belum berjalan secara baik. Salah satu contoh tujuan pendidikan nasional belum tercapai adalah kurangnya pemerataan pendidikan. Selain itu, yang mempengaruhi belum tercapainya tujuan pendidikan nasional yaitu kebiasaan pembelajaran yang masih didominasi oleh guru dan siswa hanya sebagai pendengar yang bersifat pasif. Untuk mengatasi permasalahan ini maka diperlukan perubahan paradigma yang mengarahkan siswa menjadi lebih aktif.

Berdasarkan hasil observasi di kelas IVA dan IVB SD Negeri 1 Astina pada Rabu, 18 November 2015 masih banyak siswa yang pasif dalam mengikuti pelajaran IPA di kelas. Siswa cenderung mendengarkan guru akan tetapi tidak memahami apa yang yang disampaikan oleh guru. Bahkan ada juga siswa yang sama sekali tidak mendengarkan penjelasan guru dan melakukan aktivitas lain, misalnya mencorat-coret buku tulisnya atau menggambar di buku tulisnya, mengobrol dengan temannnya bahkan setelah ditegur oleh guru siswa hanya mampu fokus mengikuti pembelajaran kurang lebih hanya 5 menit dan akan kembali mengulangi kegiatanya yang sebelumnya dilakukan.

Dari hasil wawancara dengan Guru Kelas IVA dan IVB SD Negeri 1 Astina masalah yang ditemukan adalah rendahnya minat belajar siswa dalam belajar IPA, hal ini terihat dari keadaan siswa di kelas yang masih pasif. Siswa dalam mengemukakan pendapat masih takut, karena kurang aktif dan minat belajar siswa yang masih rendah dalam mengemukakan pendapat siswa akan kesusahan dan cenderung malas untuk mengemukakan pendapatnya di dalam kelas. Dalam penerapan model pembelajaran di kelas guru belum tahu banyak model pembelajaran yang inovatif.

Selain hal tersebut, informasi yang didapat dari hasil wawancara yaitu berkenaan dengan keterampilan proses sains yang dimiliki siswa masih rendah. Dalam satu semester guru mengajak siswa melakukan kegiatan mengamati dan melakukan praktikum hanya 1-3 kali dalam satu semester, hal tersebut dapat dikategorikan kurang dari $50 \%$ karena pertemuan pembelajaran IPA dalam satu semester lebih dari 8 kali. Hal ini dapat menyebabkan keterampilan proses sains siswa tidak berkembang. Sehingga, siswa tidak dapat terampil dalam menyusun hipotesis, melakukan pengamatan, membaca grafik, menentukan variable percobaan, menginterpretasi data dan menarik kesimpulan. Akibatnya, siswa akan sulit menerapkan keterampilan proses sains dalam kehidupan sehari-hari.

Dari pencatatan dokumen didapatkan data bahwa nilai UTS siswa kelas IVA dan IVB SD Negeri 1 Astina belum mencapai KKM yang telah ditetapkan sejumlah 75. Dari hasil pencatatan dokumen yang telah dilakukan diketahui $85 \%$ siswa belum memenuhi KKM dan $15 \%$ siswa yang memenuhi KKM.

Untuk mencapai hasil pembelajaran yang lebih baik, maka diupayakan untuk menerapkan model pembelajaran Inkuiri Terbimbing. 
Pembelajaran Inkuiri Terbimbing adalah sesuatu yang sangat menantang dan melahirkan interaksi antara yang diyakini anak sebelumnya terhadap suatu bukti baru untuk mencapai pemahaman yang lebih baik, melalui proses dan metode eksplorasi untuk menurunkan, dan mengetes gagasan-gagasan baru.

Fokus persoalan yang mau didalami harus jelas arahnya dan dapat dipecahkan siswa. Pada pembelajaran yang menerapkan model pembalajaran Inkuiri Terbimbing ini, terdapat langkah-langkah pembelajaran yang mengajak siswa untuk menemukan masalah dan siswa akan lebih dilatih untuk mengembangkan pemahamannya akan konsep-konsep IPA, melalui suatu proses untuk memperoleh dan mendapatkan informasi dengan melakukan observasi atau eksperimen untuk mencari jawaban atau memecahkan masalah terhadap pertanyaan atau rumusan masalah dengan menggunakan pemikiran logis (Suastra, 2009).

Suryobroto (2009) menyatakan bahwa ada beberapa kelebihan dari model pembelajaran inkuiri terbimbing, yaitu membantu siswa mengembangkan atau memperbanyak persediaan dan penguasaan keterampilan dan proses kognitif siswa, memberi kesempatan pada siswa untuk bergerak maju sesuai dengan kemampuan, siswa terlibat langsung dalam belajar sehingga termotivasi untuk belajar, dan strategi ini berpusat pada anak.

Tugas seorang guru atau pendidik disekolah tidak lain untuk membantu perkembangan siswa, agar perkembangan pesesiswa menjadi optimal, berilah kemudahan-kemudahan dalam belajar dan janganlah guru mempersulit perkembangan belajar peserta didik karena akan berakibat fatal kepada peserta didik. Berikanlah sebuah pujian, ganjaran atau sebuah hadiah, karena itu sangat membuat minat belajar peserta didik muncul, guru-guru juga dapat membangkitkan minat belajar melalui pemberian pujian, ganjaran, atau kalau perlu hadiah. Hasil penelitian yang membuktikan bahwa penerapan inkuiri terbimbing telah menemukan keberhasilan.

Bilgin (2009) menyatakan bahwa siswa pada kelompok eksperimen yang diberikan model pembelajaran inkuiri terbimbing yang bekerja dalam model pembelajaran pembelajaran kooperatif menunjukkan skor penampilan yang lebih baik diakhir pada skala pengajaran inkuiri terbimbing terhadap tingkah laku dibandingkan dengan siswa grup control yang dibelejarkan dengan model inkuiri terbimbing secara individual. Hasil penelitian Bilgin tersebut membuktikan bahwa inkuiri terbimbing lebih unggul jika dibelajarkan dengan model pembelajaran kooperatif dibandingkan jika diajarkan secara individu.

Tujuan dari penelitian ini adalah (1) menganalisis perbedaan yang signifikan keterampilan proses sains antara kelompok siswa yang dibelajarkan menggunakan model pembelajaran inkuiri terbimbing dan antara kelompok siswa yang dibelajarkan menggunakan model pembelajaran konvensional pada siswa Kelas IV SD Negeri 1 Astina Tahun Pelajaran 2015/2016 (2) menganalisis perbedaan yang signifikan keterampilan proses sains antara kelompok siswa yang dibelajarkan menggunakan model pembelajaran inkuiri terbimbing dan antara kelompok siswa yang dibelajarkan menggunakan model pembelajaran konvensional setelah mengontrol minat belajar pada siswa Kelas IV SD Negeri 1 Astina Tahun Pelajaran 2015/2016, dan (3) menganalisis korelasi yang signifikan antara minat belajar dengan keterampilan proses sains pada siswa Kelas IV SD Negeri 1 Astina Tahun Pelajaran 2015/2016.

\section{METODE}

Jenis penelitian yang dilakukan adalah penelitian eksperimen. Penelitian eksperimen merupakan penelitian yang digunakan untuk mencari pengaruh perlakuan tertentu terhadap yang lain dalam kondisi yang terkendali (Sugiyono, 2013). Pada penelitian ini yang diuji keefektifannya adalah penerapan pembelajaran dengan model pembelajaran Inkuiri Terbimbing dan pembelajaran dengan pembelajaran konvensional terhadap keterampilan proses sains dengan mengontrol minat belajar siswa.

Penelitian ini merupakan penelitian eksperimen semu (quasi experiment) yang dilaksanakan di SD Negeri 1 Astina dengan jumlah populasi 53 siswa. Penelitian menggunakan rancangan Non-equivalent Post Test Only Control Group Design. yang secara prosedural mengikuti pola seperti ditunjukkan pada Tabel 1. 
Tabel 1. Rancangan Penelitian

\begin{tabular}{lcc}
\hline Kelas & Treatment & Post-test \\
\hline Eksperimen & $\mathrm{X}_{1}$ & $\mathrm{O}_{1}$ \\
Kontrol & - & $\mathrm{O}_{2}$ \\
\hline
\end{tabular}

(Dimodifikasi dari Gall, et al., dalam Agung, 2014:163)

$\begin{array}{lll}\text { Keterangan: } & \\ \mathrm{O} 1= & \text { post-test terhadap kelompok eksperimen } \\ \mathrm{O} 2= & \text { post-test terhadap kelompok kontrol } \\ \mathrm{X} 1= & \text { treatment terhadap kelompok eksperimen (model Inkuiri Terbimbing) } \\ -\quad= & \text { kelompok kontrol (pembelajaran konvensional) }\end{array}$

Dari rancangan penelitian di atas dapat dijelaskan bahwa dalam penelitian terdapat kelas eksperimen dan kelas kontrol. Kemudian pada kelas eksperimen diberikan perlakuan atau treatment berupa model pembelajaran inkuiri $\left(\mathrm{X}_{1}\right)$ sedangkan pada kelas kontrol tidak mendapat perlakuan atau treatment (tetap menggunakan pembelajaran konvensional). Pada awal pertemuan di kelas eksperimen dan kelas kontrol sama-sama diberikan kuesioner $\left(\mathrm{O}_{2}\right)$ berupakuesioner minat belajar dan pada akhir pertemuan di kelas eksperimen dan kelas kontrol sama-sama diberikan post-test $\left(\mathrm{O}_{1}\right)$ berupa tes keterampilan proses sains.

Pengambilan sampel pada penelitian ini dilakukan dengan teknik random sampling. Sebelum menentukan sampel penelitian, populasi tersebut diuji kesetaraannya berdasarkan nilai UTS IPA semester ganjil dengan uji-t. Berdasarkan hasil uji kesetaraan yang dilakukan dengan program SPSS 16.0 for windows, diketahui bahwa kemampuan siswa di SD Negeri 1 Astina tersebut telah setara.

Berdasarkan uji kesetaraan yang telah dilakukan dibantu dengan aplikasi SPSS 16.0 for windows diketahui bahwa signifikansi nila UTS IPA pada populasi tersebut adalah 0,340 . Hal ini menunjukkan bahwa $\mathrm{H}_{0}$ diterima $(0,340>0.05)$ yang artinya nilai UTS IPA kedua kelas setara (sama)

Setelah diketahui bahwa populasi yang digunakan dalam penelitian ini telah setara, selanjutnya menentukan sampel penelitian berdasarkan teknik random sampling. Berdasarkan teknik tersebut, akhirnya terpilih kelas IVA sebagai kelompok eksperimen dan kelas IVB sebagai kelompok kontrol.
Metode pengumpulan data yang digunakan adalah tes uraian dan kuesioner. Tes yang digunakan adalah tes keterampilan proses sains dan kuesioner yang digunakan adalah kuesioner minat belajar. Data yang dikumpulkan dianalisis menggunakan analisis deskriptif dan Anava 1 jalur, Anakova 1 jalur 1 kovariabel dan korelasi product-moment.

\section{HASIL DAN PEMBAHASAN}

\section{Hasil}

Berdasarkan analisis data yang telah dilakukan terhadap skor keterampilan proses sains, diperoleh hasil seperti yang tersaji pada Tabel 2.

Tabel 2. Deskripsi Skor Keterampilan Proses Sains

\begin{tabular}{lll}
\hline & \multicolumn{1}{c}{$\mathrm{A}_{1} \mathrm{Y}$} & \multicolumn{1}{c}{$\mathrm{A}_{2} \mathrm{Y}$} \\
\hline Rata-rata & 17,92 & 13,88 \\
Median & 16,50 & 12,00 \\
Modus & 16,00 & 6,00 \\
Std. Deviasi & 7,817 & 6,09 \\
Varians & 61,10 & 37,11 \\
Rentangan & 34,00 & 20,00 \\
Skor Minimum & 3,00 & 6,00 \\
Skor Maksimum & 37,00 & 26,00 \\
\hline Jumlah & 193,35 & 127,08 \\
\hline
\end{tabular}

Keterangan:

$\mathrm{A}_{1} \mathrm{Y}=$ Hasil post-test kelompok yang diberikan inkuiri terbimbing.

$\mathrm{A}_{2} \mathrm{Y}=$ Hasil post-test kelompok konvensional. 
Berdasakan Tabel 2, diketahui rata-rata, diperoleh skor keterampilan proses sains untuk kelompok siswa yang dibelajarkan dengan model Inkuiri Terbimbing sebesar 17,93 dan standar deviasi $=8$. Hal ini berarti skor rata-rata keterampilan proses sains siswa yang dibelajarkan dengan model Inkuiri Terbimbing berada pada kategori cukup. Skor keterampilan proses sains siswa yang dibelajarkan dengan pembelajaran konvensional memiliki skor rata-rata sebesar 13,88 dan standar deviasi $=6$. Hal ini berarti bahwa skor rata-rata keterampilan proses sains siswa yang dibelajarkan dengan pembelajaran konvensional termasuk dalam kategori kurang baik. Rata-rata dari hasil ini mengindikasikan bahwa hasil akhir keterampilan proses sains antara siswa yang dibelajarkan dengan model Inkuiri Terbimbing dan siswa yang dibelajarkan dengan pembelajaran konvensional memiliki tingkat keterampilan proses sains yang berbeda. Dengan kata lain, kelompok siswa yang dibelajarkan dengan model Inkuiri Terbimbing memiliki tingkat keterampilan proses sains yang lebih baik dibandingkan dengan kelompok siswa yang dibelajarkan dengan pembelajaran konvensional.

Sebelum melakukan pengujian hipotesis, terlebih dahulu dilakukan uji prasyarat yaitu homogenitas, uji normalitas, dan uji linearitas. Setelah dilakukan uji prasyarat diketahui bahwa data keterampilan proses sains berdistribusi normal, homogen dan linear. Setelah dilakukan uji prasyarat dilanjutkan dengan pengujian hipotesis ke-1 dengan uji Anava 1 jalur, hipotesis ke-2 dengan Anakova 1 jalur 1 kovariabel dan hipotesis ke-3 diuji dengan korelasi productmoment. Hasil pengujian hipotesis ke-1 disajikan pada Tabel 3.

Tabel 3. Hasil Uji Anava 1 Jalur (Uji Hipotesis ke-1)

\begin{tabular}{lrrrrr}
\hline & \multicolumn{1}{c}{ JK } & Db & \multicolumn{1}{c}{ RJK } & F & \multicolumn{1}{c}{ Sig. } \\
\hline Antar & 216,484 & 1 & 216,484 & 4,346 & 0,042 \\
Dalam grup & 2540,497 & 51 & 49,814 & & \\
\hline Total & 2756,981 & 52 & & & \\
\hline
\end{tabular}

Hasil analisis pada Tabel 3. menunjukkan bahwa nilai $\mathrm{F}$ untuk sumber data antar model pembelajaran sebesar 4,346 dengan signifikansi sebesar 0,042 (Sig. < 0,05). Ini berarti $\mathrm{H}_{0}$ ditolak, atau $\mathrm{H}_{1}$ diterima. Dengan kata lain dapat disimpulkan bahwa terdapat perbedaan keterampilan proses sains yang signifikan antara kelompok siswa yang dibelajarkan dengan model pembelajaran Inkuiri Terbimbing dengan pembelajaran konvensional pada siswa kelas IV SD Negeri 1 Astina Tahun Pelajaran 2015/2016.

Setelah diketahui hasil uji hipotesis ke-1 dilanjutkan dengan uji hipotesis ke-2 yaitu dengan uji Anakova 1 jalur 1 kovariabel yang tersaji pada Tabel 4.

Tabel 4. Hasil Uji Anakova 1 Jalur 1 kovariabel (Uji Hipotesis ke-2)

\begin{tabular}{lrrrrr}
\hline \multicolumn{1}{c}{ Sumber } & \multicolumn{1}{c}{ JK } & \multicolumn{1}{c}{ db } & \multicolumn{1}{c}{ RJK } & \multicolumn{1}{c}{ F } & \multicolumn{1}{c}{ Sig. } \\
\hline X & 884,936 & 1 & 884,936 & 26,726 & 0,000 \\
A & 137,408 & 1 & 137,408 & 4,150 & 0,047 \\
Dalam Grup & 1655,561 & 50 & 33,111 & & \\
\hline Total & 2756.981 & 52 & & & \\
\hline
\end{tabular}

Berdasarkan Tabel 4, nampak bahwa skor keterampilan proses sains pada kelompok siswa yang dibelajarkan dengan model pembelajaran Inkuiri Terbimbing dengan kelompok siswa yang dibelajarkan dengan pembelajaran konvensional setelah mengontrol minat belajar siswa diperoleh skor $\mathrm{F}_{\text {hitung }}=4,150$ dengan signifikansi $0,047(<$ $0,05)$. Dengan demikian hipotesis nol $\left(\mathrm{H}_{0}\right)$ ditolak dan hipotesis alternative $\left(\mathrm{H}_{1}\right)$ diterima. Dengan demikian, dapat disimpulkan bahwa terdapat perbedaan keterampilan proses sains yang signifikan antara kelompok siswa yang dibelajarkan dengan model pembelajaran Inkuiri Terbimbing dengan kelompok siswa yang dibelajarkan dengan pembelajaran konvensional setelah mengontrol minat belajar siswa Kelas IV SD Negeri 1 Astina Tahun Pelaxjaran 2015/2016. 
Pengujian hipotesisi ke-3 dilakukan dengan uji korelasi product moment. Pengujian ini bertujuan untuk mengetahui seberapa besar korelasi antara minat belajar (X) dan keterampilan proses sains (Y). Pengujian dilakukan dengan program SPSS 16.0 for windows.

Hasil analisis korelasi product moment menunjukkan bahwa skor signifikansi korelasi minat belajar terhadap keterampilan proses sains adalah sebesar 0,000. Koefisien korelasi sebesar 0,591 menunjukkan bahwa korelasi antara minat belajar dan keterampilan proses sains berada dalam kategori "Sedang", sementara skor positif mengindikasikan pola hubungan antara minat belajar dan keterampilan proses sains adalah searah (semakin tinggi minat belajar maka semakin tinggi pula keterampilan proses sains). Perolehan signifikansi sebesar $0,000<0.05$ menunjukkan bahwa $\mathrm{H} 0$ ditolak, atau $\mathrm{H}_{1}$ diterima. Dengan demikian, dapat disimpulkan bahwa terdapat korelasi yang signifikan antara minat belajar terhadap keterampilan proses sains siswa Kelas IV SD Negeri 1 Astina Tahun Pelajaran 2015/2016.

\section{Pembahasan}

Hasil penelitian ini menunjukkan bahwa ratarata skor keterampilan proses sains siswa kelas IV yang dibelajarkan dengan model Inkuiri Terbimbing lebih tinggi dibandingkan dengan rata-rata skor keterampilan proses sains siswa yang dibelajarkan dengan pembelajaran konvensional. Hal ini ditunjukkan dengan nilai $\mathrm{F}$ $=4,346$ pada sig $(0,002)<0,05$. Hal ini mengindikasikan bahwa model pembelajaran Inkuiri Terbimbing lebih unggul dibandingkan dengan model pembelajaran konvensional.

Perbedaan keterampilan proses sains yang signifikan ini dapat dijelaskan karena pembelajaran dengan pendekatan Inkuiri Terbimbing memberikan peluang besar kepada siswa untuk berperilaku aktif terlibat langsung dalam proses pembelajaran. Pembelajaran dengan pendekatan Inkuiri Terbimbing dalam proses pembelajaran guru harus memberikan pengarahan dan bimbingan kepada siswa dalam melakukan kegiatan-kegiatan sehingga siswa yang berpikir lambat atau siswa yang mempunyai intelegensi rendah tetap mampu mengikuti kegiatan pembelajaran yang sedang dilaksanakan dan siswa tidak memonopoli pembelajaran, oleh sebab itu guru harus memiliki kemampuan mengelola kelas yang bagus, sehingga pada saat proses pembelajaran, tercipta suasana yang efektif dan menyenangkan untuk dapat membantu siswa memahami materi pelajaran. Guru memberikan masalah kepada siswa, kemudian siswa diarahkan untuk merumuskan masalah dari permasalahan yang ada. Setelah rumusan masalah ada kemudian siswa membuat jawaban sementara dari rumusan masalah yang diajukan.

Dalam menyelesaikan masalah siswa juga memerlukan buku-buku sumber untuk membantu menyelesaikan masalah yang ada. Dalam menyelesaikan masalah yang diberikan siswa melakukan percobaan. Setelah melakukan percobaan siswa membuat kesimpulan dari hasil percobaan sudah dilakukan. Untuk mencapai kesimpulan yang akurat sebaiknya guru mampu menunjukkan pada siswa data mana yang relevan.

Berbeda halnya dengan pembelajaran yang menggunakan pendekatan konvensional, proses pembelajaran didominasi oleh guru. Pembelajaran konvensional lebih menekankan bagaimana guru dapat menjelaskan materi ajar dengan baik dan memberi pentunjuk mengenai apa yang harus dilakukan oleh siswa. Pembelajaran yang demikian kurang memberikan pengalaman kepada siswa sehingga siswa cepat merasa bosan karena rendahnya ketertarikan siswa untuk belajar.

Berdasarkan uraian tersebut, pembelajaran dengan menggunakan pendekatan Inkuiri Terbimbing memberikan kesempatan kepada siswa untuk berperan aktif untuk mencari informasi sebanyak-banyaknya. Dalam pembelajaran ini, guru hanya berfungsi menjadi fasilitator, mediator, dan motivator, sehingga siswalah yang harus aktif dalam membangun pengetahuannya.

Suryobroto (2009) menyatakan bahwa kelebihan model pembelajaran Inkuiri Terbimbing antara lain, membantu siswa mengembangkan penguasaan keterampilan dan proses kognitif siswa, membangkitkan gairah pada siswa misalkan siswa merasakan jerih payah penyelidikannya, menemukan keberhasilan dan kadang-kadang kegagalan, memberi kesempatan pada siswa untuk bergerak maju sesuai dengan kemampuan, siswa terlibat langsung dalam belajar sehingga termotivasi untuk belajar, strategi ini berpusat pada siswa, misalkan memberi kesempatan kepada mereka dan guru berpartisipasi sebagai sesama dalam mengecek 
ide. Guru menjadi teman belajar, terutama dalam situasi penemuan yang jawabanya belum diketahui.

Hasil uji hipotesis pertama telah menunjukkan bahwa keterampilan proses sains kelompok siswa yang mengikuti pembelajaran dengan pendekatan Inkuiri Terbimbing lebih baik daripada kelompok siswa yang mengikuti pembelajaran dengan pendekatan konvensional. Dengan demikian, sangatlah tepat pendekatan Inkuiri Terbimbing akan meningkatkan keterampilan proses sains siswa, karena merupakan suatu pendekatan pembelajaran yang mengharapkan siswa sendiri yang mengkontruksi pengetahuannya, sedangkan pembelajaran dengan pendekatan konvensional siswa memperoleh informasi yang bersumber dari guru dan buku saja.

Keterampilan proses sains siswa dipengaruhi oleh dua faktor yaitu faktor eksternal (model pembelajaran) dan faktor internal (minat belajar). Perbedaan perlakuan berupa model pembelajaran yang diterapkan pada setiap kelompok siswa dan minat belajar yang dimiliki siswa menyebabkan keterampilan proses sains siswa baik pada kelompok eksperimen maupun kelompok kontrol menunjukkan hasil yang berbeda.

Thohiron (2009) berpendapat bahwa pembelajaran Inkuiri Terbimbing yaitu suatu model pembelajaran inkuiri yang dalam pelaksanaannya guru menyediakan bimbingan atau petunjuk cukup luas kepada siswa. Model pembelajaran Inkuiri Terbimbing merupakan model pembelajaran yang dalam proses pembelajaran guru harus memberikan pengarahan dan bimbingan kepada siswa dalam melakukan kegiatan-kegiatan sehingga siswa yang berpikir lambat atau siswa yang mempunyai intelegensi rendah tetap mampu mengikuti kegiatan pembelajaran yang sedang dilaksanakan. Jika siswa yang memiliki minat belajar rendah, jika diberikan model pembelajaran yang menyenangkan dan menuntut keaktifan siswa, maka secara perlahan akan lebih menimbulkan minat belajar pada diri siswa dan pada akhirnya bermuara pada hasil belajar yang optimal pula.

Dapat disimpulkan bahwa setelah minat belajar siswa dikendalikan, tetap terdapat perbedaan keterampilan proses sains antara kedua kelompok. Perbedaan keterampilan proses sains secara signifikan dipengaruhi oleh model yang digunakan dalam pembelajaran.

Berdasarkan hasil uji korelasi keterampilan proses sains dengan minat belajar siswa menggunakan product moment, tampak bahwa koefisien korelasi minat belajar positif (searah) terhadap keterampilan proses sains. Koefisien korelasi product moment menunjukkan skor sebesar 0,418 dengan signifikansi sebesar 0,002. Sesuai dengan pedoman interpretasi koefisien korelasi yang dikemukakan oleh Sugiyono (2009:231), koefisien korelasi sebesar 0,418 ini termasuk dalam kategori "Sedang". Sedangkan skor positif mengindikasikan pola hubungan antara keterampilan proses sains dan minat belajar adalah searah (semakin tinggi minat belajar maka semakin tinggi pula keterampilan proses sains). Hal ini menunjukkan bahwa untuk mencapai keterampilan proses sains yang baik, seorang guru harus mampu merancang sebuah pembelajaran yang dapat meningkatkan minat belajar siswa. Perolehan skor Sig. $=0.002<0.05$ yang menandakan bahwa hubungan yang terjadi antara minat belajar dan keterampilan proses sains adalah signifikan.

Minat mempunyai peranan yang sangat penting dalam proses belajar mengajar. Oleh karena itu, seorang guru hendaknya harus selalu berusaha untuk menumbuhkan dan meningkatkan minat siswa terhadap pelajaran yang diajarkan. Safari (dalam Wasti, 2013) indikator minat belajar ada 4 yaitu: (1) perasaan senang, (2) ketertarikan siswa, (3) perhatian, (4) keterlibatan siswa.

Dalam proses pembelajaran, setiap siswa memiliki minat belajar yang berbeda. Sering dijumpai beberapa siswa yang merespon dan memberikan reaksi terhadap apa yang disampaikan guru pada saat proses belajar mengajar di kelas. Perhatian, semua siswa yang mempunyai minat terhadap pelajaran tertentu akan cenderung memberikan perhatian besar terhadap pelajaran itu. Keterlibatan, keuletan dan kerja keras yang tampak melalui diri siswa menunjukkan bahwa siswa tersebut ada keterlibatannya dalam belajar dimana siswa selalu lebih giat, berusaha menemukan hal-hal yang baru yang berkaitan dengan pelajaran yang diberikan guru di sekolah.

Siswa memiliki minat yang tinggi akan memberikan sumbangan besar pula pada pencapaian tujuan pembelajaran maupun keberhasilan belajar peserta didik. Begitupula dengan korelasi minat belajar terhadap keterampilan proses sains, siswa yang memiliki minat belajar yang tinggi akan perhatian dan belajar dengan sungguh-sungguh, sehingga dalam menerapkan dimensi keterampilan proses sains 
dapat dilakukan dengan baik oleh siswa yang minat belajarnya tinggi.

Dengan demikian, keterampilan proses sains siswa sangat bergantung pada minat belajar yang mereka miliki. Semakin tinggi minat belajar siswa, maka semakin tinggi pula keterampilan proses sains yang dimiliki. Sebaliknya, semakin rendah minat belajar siswa, maka semakin rendah pula keterampilan proses sains yang dimiliki.

Hasil penelitian ini didukung oleh hasil penelitian Marheni, dkk (2014) mengenai Studi Komparasi Model Pembelajaran Inkuiri Terbimbing dan Model Pembelajaran Inkuiri Bebas Terhadap Hasil Belajar dan Keterampilan Proses Sains Siswa Pada Pembelajaran Sains SMP. Dengan hasil penelitian siswa yang belajar dengan menggunakan model pembelajaran Inkuiri Terbimbing memiliki rata-rata sebesar 32,61 dengan standar deviasi 10,08. Sedangkan untuk model pembelajaran inkuiri bebas memiliki ratarata sebesar 28,67 dengan standar deviasi sebesar 8,77 . Hal ini mengindikasikan bahwa dalam pencapaian keterampilan proses sains siswa untuk siswa yang mengikuti model pembelajaran Inkuiri Terbimbing memberikan hasil yang lebih baik dibandingkan dengan siswa untuk siswa yang mengikuti model pembelajaran inkuiri bebas.

Hasil penelitian ini juga didukung oleh hasil penelitian Hermawati (2012) yang menyatakan bahwa, siswa dengan minat belajar yang rendah akan berpengaruh pada proses pembelajaran yang berlangsung. Ketiadaan minat terhadap pelajaran menjadi penyebab kurang bersemangatnya siswa dalam melakukan aktivitas pembelajaran.

Berdasarkan hasil penelitian dan temuan tersebut, maka keterampilan proses sains antara kelompok siswa yang dibelajarkan dengan model Inkuiri Terbimbing mempunyai pengaruh lebih besar dibandingkan dengan kelompok siswa yang dibelajarkan dengan pembelajaran konvensional pada siswa kelas IV SD Negeri 1 Astina Tahun Pelajaran 2015/2016.

\section{SIMPULAN}

Hasil pengujian terhadap ketiga hipotesis yang diajukan pada penelitian ini menghasilkan simpulan sebagai berikut. 1) Terdapat perbedaan keterampilan proses sains yang signifikan antara kelompok siswa yang dibelajarkan dengan model pembelajaran Inkuiri Terbimbing dengan pembelajaran konvensional pada siswa kelas IV
SD Negeri 1 Astina Tahun Pelajaran 2015/2016 $(\mathrm{F}=4,346$; Sig. < 0,05). 2) Terdapat perbedaan keterampilan proses sains yang signifikan antara kelompok siswa yang dibelajarkan dengan model pembelajaran Inkuiri Terbimbing dengan kelompok siswa yang dibelajarkan dengan pembelajaran konvensional setelah mengontrol minat belajar siswa Kelas IV SD Negeri 1 Astina Tahun Pelajaran 2015/2016 (F = 6,792; Sig. < $0,05)$. Dengan demikian setelah minat belajar siswa dikendalikan, terdapat perbedaan yang signifikan keterampilan proses sains antara kelompok siswa yang mengikuti pembelajaran dengan model Inkuiri Terbimbing dan kelompok siswa yang mengikuti pembelajaran konvensional. 3) Korelasi yang diberikan variabel pengendali terhadap keterampilan proses sains siswa pada kedua kelompok memberikan korelasi yang positif. Untuk kelompok siswa yang mengikuti pembelajaran dengan model Inkuiri Terbimbing dan kelompok siswa yang mengikuti pembelajaran konvensional, diperoleh koefisien korelasi $=0,418$ dengan signifikansi 0,002 . Berdasarkan uraian di atas dapat disimpulkan bahwa minat belajar memberikan korelasi positif terhadap keterampilan proses sains siswa.

Berdasarkan temuan-temuan dari penelitian ini, maka dikemukakan saran-saran yaitu, 1) Siswa-siswa sekolah dasar agar selalu terlibat secara aktif dalam proses pembelajaran agar dapat mengembangkan pemahaman dan mendapatkan pengetahuan baru melalui pengalaman yang ditemukan sendiri. 2) Guru hendaknya melakukan inovasi dalam pembelajaran dengan cara memilih dan menggunakan model dalam mengajar yang sesuai dengan kebutuhan siswa dan sesuai dengan karakter siswa. 3) Penelitian ini diharapkan dapat memberikan kontribusi bagi sekolah dalam pengembangan pendidikan karena bertambahnya ragam atau variasi pendekatan pembelajaran. 4) Penelitian ini dapat dijadikan acuan ataupun referensi bagi peneliti lain yang berminat untuk mengadakan penelitian lebih lanjut mengenai model pembelajaran Inkuiri Terbimbing dengan memperhatikan kendala-kendala yang dialami sebagai bahan pertimbangan untuk menyempurnakan pelaksanaan penelitian selanjutnya. 


\section{DAFTAR RUJUKAN}

Bilgin, Ibrahim. 2009. "The Effects Of Guided Inquiry Instruction Incorporating A Cooperative Learning Approach On University Students' Achievement Of Acid And Bases Concepts And Attitude Toward Guided Inquiry Instruction". Jurnal: Inkuiri Terbimbing. Volume 4

Hermawati, Manik IW. 2012. "Pengaruh Model Pembelajaran Inkuiri terhadap Penguasan Konsep Biologi dan Sikap Ilmiah Siswa SMA Ditinjau dari Minat Belajar Siswa". Tesis (tidak diterbitkan) Program Studi Pendidikan Sains Pascasarjana Universitas Pendidikan Ganesha.

Marheni, dkk. 2014. "Studi Komparasi Model Pembelajaran Inkuiri Terbimbing dan Model Pembelajaran Inkuiri Bebas Terhadap Hasil Belajar dan Keterampilan Proses Sains Siswa Pada Pembelajaran Sains SMP”. Tersedia pada http://pasca.undiksha.ac.id/ejournal/index.p hp/jurnalipa/article/viewFile/1286/988 (diakses pada 15 Januari 2016).

Sardini. 2013. "Pengaruh Minat Belajar Terhadap Hasil Belajar Pelajaran Ekonomi Siswa Kelas Xi IPS Man Pontianak". Artikel: Minat Belajar

Suastra, I Wayan. 2009. Pembelajaran Sains Terkini Mendekati Siswa dengan Alamiah dan Sosial Budayanya. Singaraja: Undiksha

Sugiyono, 2013. Metode Penelitian Pendidikan. Bandung: Alfabeta.

Suryobroto. 2009. Proses Belajar dan Mengajar di Sekolah. Jakarta: Rineka Cipta.

Undang-Undang No. 20 Tahun 2003 tentang Sistem Pendidikan Nasional, 2003. Jakarta: Depdiknas.

Wasti, Sriana. 2013. Hubungan Minat Belajar dengan Hasil Belajar Mata Pelajaran Tata Busana di Madrasah Aliyah Negeri 2 Padang". Tersedia pada http://ejournal.unp.ac,id/index,php/jhet/arti cle/viewFile/1032/869 (diakses tanggal 15 Maret 2016). 